\title{
HUBUNGAN SIKAP IBU DENGAN KELENGKAPAN IMUNISASI DASAR DI WILAYAH KERJA PUSKESMAS SEKINCAU KABUPATEN LAMPUNG BARAT
}

\author{
Yuliati Amperaningsih*, Yunanda Ayu Aprilia* \\ *Jurusan Keperawatan Poltekes Tanjungkarang
}

\begin{abstract}
Menurut Word Health Organization (WHO)/United Nation Children's Fund (UNICEF) tahun 2015, hampir satu juta anak Indonesia tidak mendapatkan imunisasi sama sekali atau tidak lengkap status imunisasinya. Pada tahun 2015 Indonesia memiliki cakupan imunisasi 92,3\% dan turun kembali pada tahun 2016 sebesar $86,5 \%$. Faktor penyebab ketidakberhasilan imunisasi diantaranya adalah sikap orang tua anak berkaitan pemberian imunisasi dasar. Tujuan umum dari penelitian ini adalah untuk mengetahui hubungan antara sikap ibu dengan kelengkapan imunisasi di wilayah kerja Puskesmas Sekincau Kabupaten Lampung Barat. Jenis penelitian kuantitaitf dengan pendekatan cross sectional. Populasi adalah keseluruhan ibu yang memiliki balita di wilayah kerja Puskesmas Sekincau dengan jumlah sampel sebanyak $91 \mathrm{ibu}$. Data dianalisis univariat dan bivariat dengan uji chi square. Hasil penelitian diperoleh distribusi frekuensi sikap ibu terhadap kelengkapan imunisasi dasar terbanyak dengan sikap yang tidak mendukung sebesar 50,55\% (46 orang). Distribusi frekuensi kelengkapan imunisasi dasar pada balita terbanyak dengan imunisasi dasar yang tidak lengkap sebesar 63,74\% (58 orang). Ada hubungan sikap ibu tentang imunisasi dasar lengkap dengan kelengkapan imunisasi dasar lengkap di wilayah kerja Puskesmas Sekincau Kabupaten Lampung barat Tahun 201 dengan $p$ value: 0,007 OR: 3,764. Saran diharapkan pihak puskesmas lebih gencar melakukan sosialisasi pelaksanaan imunisasi dasar lengkap guna meningkatkan cakupan pemberian imunisasi dasar lengkap kepada bayi di wilayah kerjanya.
\end{abstract}

Kata kunci: Sikap ibu, Imunisasi Dasar

\section{LATAR BELAKANG}

Setiap tahun lebih dari 1,4 juta anak di dunia meninggal. Berdasarkan hasil Survei Demografi Kesehatan Indonesia (SDKI) tahun 2012, angka kematian bayi (AKB) 34/1000 kelahiran hidup dan angka kematian balita (AKBA) 44/1000 kelahiran hidup karena berbagai penyakit yang sebenarnya dapat dicegah dengan imunisasi. Imunisasi adalah suatu upaya untuk menimbulkan/meningkatkan kekebalan seseorang secara aktif terhadap suatu penyakit, sehingga bila suatu saat terpapar dengan penyakit tersebut tidak akan sakit atau hanya mengalami sakit ringan. Beberapa penyakit menular yang termasuk ke dalam Penyakit yang Dapat Dicegah dengan Imunisasi (PD3I) antara lain Tuberkulosis, Difteri, Tetanus, Hepatitis B, Pertusis, Campak, Polio, radang selaput otak, dan radang paru-paru. Anak yang telah diberi imunisasi akan terlindungi dari berbagai penyakit berbahaya tersebut, yang dapat menimbulkan kecacatan atau kematian
Menurut angka estimasi yang dikeluarkan oleh World Health Organization (WHO)/United Nation Children's Fund (UNICEF) tahun 2015, hampir satu juta anak Indonesia tidak mendapatkan imunisasi sama sekali atau tidak lengkap status imunisasinya (Kemenkes, 2016).

Indonesia memiliki cakupan imunisasi yang sedikit lebih rendah daripada tahun 2014 sebesar 94,7 yaitu sebesar 92,3\% pada tahun 2015. Program imunisasi pada bayi bertujuan agar setiap bayi mendapatkan imunisasi dasar secara lengkap. Keberhasilan seorang bayi dalam mendapatkan imunisasi dasar tersebut diukur melalui indikator imunisasi dasar lengkap. Capaian indikator ini di Indonesia pada tahun 2015 sebesar 86,54\%. Angka ini belum mencapai target Renstra pada tahun 2015 yang sebesar 91\% (Kemenkes, 2016).

Menurut Ditjen Pencegahan dan Pengendalian Penyakit Kemenkes RI cakupan imunisasi dasar selama lima tahun dari tahun 2011 sampai tahun 2016) berturut-turut adalah 93,3\%, 86,8\%, 
$89,9 \%, 86,9 \%$, dan turun kembali pada tahun 2015 sebesar 86,5\%. Untuk propinsi Lampung cakupan imunisasi dasar lengkap sebesar 98,60\%. Persentase cakupan desa/kelurahan Universal Child Immunization (UCI) di Provinsi Lampung tahun 2015 sebesar 96\% (Dinkes Provinsi Lampung, 2016). Namun, meskipun cakupan secara nasional dan provinsi sudah mencapai target, kesenjangan cakupan di beberapa daerah masih ada. Masih terdapat anak-anak yang sama sekali belum mendapatkan imunisasi atau belum lengkap imunisasinya (Kemenkes, 2017).

Sebagai salah satu kelompok yang menjadi sasaran program imunisasi, setiap bayi wajib mendapatkan imunisasi dasar lengkap yang terdiri dari 1 dosis Bacille Calmette-Guérin (BCG), 3 dosis Difteri, Pertusis, Dan Tetanus (DPT)-Hepatitis B (HB) dan atau DPT-HB- Haemophilus Influenzae tipe $\mathrm{b}$ (Hib), 4 dosis polio, dan 1 dosis campak karena imunisasi dapat melindungi anak terhadap beberapa PD3I tersebut melalui vaksin yang disuntikkan pada lokasi tertentu atau diteteskan melalui mulut.

Dari imunisasi dasar lengkap yang diwajibkan tersebut, campak merupakan imunisasi yang mendapat perhatian lebih, hal ini sesuai komitmen Indonesia pada global untuk mempertahankan cakupan imunisasi campak sebesar 90\% secara tinggi dan merata (Kemenkes, 2016).

Imunisasi adalah suatu upaya untuk meningkatkan kekbalan individu agar terhindar dari penyakit tertentu (Lisnawati, 2011).

Vaksin adalah suatu produk biologi yang terbuat dari kuman, komponen kuman atau racun kuman yang telah dilemahkan atau dimatikan dan berguna untuk merangsang kekebalan tubuh seseorang. Imunisasi dasar yang diberikan kepada bayi yaitu BCG untuk kekebalan aktif terhadap tuberkulosis, DPT untuk kekebalan secara simultan terhadap difteri, pertusis dan tetanus, polio untuk kekebalan aktif terhadap poliomielitis, campak untuk kekebalan aktif terhadap penyakit campak dan hepatitis B untuk kekebalan aktif terhadap penyakit yang disebabkan oleh virus hepatitis B (Kemenkes RI, 2016).

Berdasarkan data cakupan UCI Puskesmas Sekincau tahun 2017, keseluruhan pekon sudah dilakukan pemberian imunisasi dasar pada bayi, meskipun terdapat beberapa daerah yang mengalami kendala dalam pemberiannya diantaranya masih kurangnya cakupan UCI yang baru mencapai $86,4 \%$, dimana hal ini masih rendah dibandingkan dengan cakupan UCI Puskesmas Liwa dan Puskesmas Fajar Bulan yang sudah mencapai $90 \%$ (Puskesmas Sekincau, 2018)

Faktor penyebab ketidakberhasilan imunisasi diantaranya adalah perilaku kesehatan dari orang tua anak Menurut Notoatmodjo (2010), individu dalam perilaku pencarian dan pemilihan pelayanan kesehatan dipengaruhi oleh beberapa faktor diantaranya faktor predisposisi yang meliputi pengetahuan, sikap, ekonomi, kebudayaan dan lain-lain.

Pra survey yang dilakukan pada bulan April 2018 diperoleh data dari 17 Posyandu di wilayah di Kelurahan Sekincau terjadi penyebaran virus mematikan difteri, penyakit menular akibat kuman corynebacterium diptheriae yang mewabah hingga adanya korban meninggal dan saat itu dilaporkan oleh Puskesmas Sekincau ada 3 orang bayi dan balita yang dilarikan ke RSUD Abdul Moeloek, dan 8 orang lainnya dilarikan ke RSUD Liwa guna penanganan cepat dan tanggap (http://www.lampung1.com). Hasil ini menunjukkan bahwa masih terdapat balita yang tidak lengkap imunisasi dasarnya baru mencapai $86,4 \%$, sehingga belum diberikan imunisasi difteri sehingga terjangkit bakteri.

\section{METODE}

Penelitian ini bersifat analitik dengan pendekatan cross sectional atau potong lintang untuk mengetahui hubungan sikap ibu terhadap imunisasi dengan kelengkapan imunisasi dasar. Populasi dalam penelitian ini adalah keseluruhan 
ibu yang memiliki balita pada 5 Desa dan 17 Posyandu dengan $1.008 \mathrm{ibu}$ yang berkunjung ke Posyandu dan memiliki Kartu Menuju Sehat (KMS). Sampel diambil menggunakan tehnik accidental sampling dimana sampel di ambil dari anggota populasi yang kebetulan ada dalam kegiatan di 17 posyandu berjumlah 91 responden.

Instrumen yang digunakan dalam penelitian ini adalah alat penilaian sikap ibu menggunakan kuisioner. Kuisioner dalam penelitian ini terdiri dari 30 pertanyaan tentang sikap ibu terhadap imunisasi dasar yang telah dilakukan uji validitas dan realibilitas sebelumnya dengan hasil yang valid dan reliabel (terlampir) hasil dari jawaban responden dikategorikan menjadi dua kategori dengan skala ordinal dan dengan kode 0 untuk sikap yang mendukung dan 1 untuk sikap yang tidak mendukung.

Tehnik pengumpulan data penelitian ini dengan menggunakan kuisioner dan buku KIA dan KMS.Teknik analisis data yang dipergunakan guna analisis univariat, data yang sejenis digabungkan, yang kemudian dibuat tabel distribusi frekuensi untuk dipresentasikan, untuk pengolahan hasil dari pengumpulan data digunakan analisa data dengan menggunakan komputerisasi. Analisa bivariat digunakan untuk melihat hubungan antara variabel independent dengan variabel dependent. Uji statistik yang digunakan adalah $U j i C h i$ Square.

\section{HASIL}

\section{Analisis Univariat}

Tabel 1: Distribusi Frekuensi Sikap ibu Tentang Imunisasi Dasar

\begin{tabular}{lcc}
\hline \multicolumn{1}{c}{ Sikap ibu } & f & $\%$ \\
\hline Tidak mendukung & 46 & 50,55 \\
\hline mendukung & 45 & 49,45 \\
\hline Jumlah & 91 & 100 \\
\hline
\end{tabular}

Distribusi frekuensi sikap ibu terhadap kelengkapan imunisasi dasar terbanyak dengan sikap yang tidak mendukung sebesar 50,55\% (46 orang).

Tabel 2: Distribusi Frekuensi Kelengkapan Imunisasi Dasar

\begin{tabular}{lcc}
\hline \multicolumn{1}{c}{ Kelengkapan imunsasi } & f & $\%$ \\
\hline Tidak lengkap & 58 & 63,74 \\
\hline Lengkap & 33 & 36,26 \\
\hline Jumlah & 91 & 100 \\
\hline
\end{tabular}

Distribusi frekuensi kelengkapan imunisasi dasar pada balita terbanyak dengan imunisasi dasar yang tidak lengkap sebesar $63,74 \%$ (58 orang).

\section{Analisis Bivariat}

Tabel 3: Distribusi Frekuensi Hubungan Sikap Ibu tentang Imunisasi Dasar dengan Kelengkapan Imunisassi Dasar

\begin{tabular}{|c|c|c|c|c|c|}
\hline \multirow{3}{*}{ Sikap Ibu } & \multicolumn{3}{|c|}{ Imunisasi Dasar } & \multirow{2}{*}{\multicolumn{2}{|c|}{ Total }} \\
\hline & Lengkap & \multicolumn{2}{|c|}{$\begin{array}{c}\text { Tidak } \\
\text { Lengkap }\end{array}$} & & \\
\hline & $\%$ & $\mathrm{f}$ & $\%$ & $\mathrm{f}$ & $\%$ \\
\hline Mendukung & 2351,1 & 22 & 48,9 & 45 & 100 \\
\hline Tidak Mendukung & $10 \quad 21,7$ & 36 & 78,3 & 46 & 100 \\
\hline Jumlah & $33 \quad 36,3$ & 58 & 63,7 & 91 & 100 \\
\hline p value & \multicolumn{3}{|l|}{0,007} & & \\
\hline OR & \multicolumn{3}{|c|}{$3,764(1,511-9,373)$} & & \\
\hline
\end{tabular}

Berdasarkan tabel di atas diketahui bahwa hasil analisis hubungan sikap ibu dengan kelengkapan imunisasi dasar dari 45 ibu dengan sikap yang mendukung terdapat 23 bayi $(51,1 \%)$ dengan imunisasi lengkap dan 22 bayi $(48,9 \%)$ dengan imunisasi tidak lengkap, sedangkan dari 46 ibu dengan sikap yang tidak mendukung terdapat 10 bayi $(21,7 \%)$ dengan imunisasi lengkap dan 36 bayi (78,3\%) dengan imunisasi yang tidak lengkap.

Hasil uji statistik chi square diperoleh bahwa nilai $\mathrm{p}$ value: 0,007 , yang berarti ada hubungan sikap ibu tentang imunisasi dasar dengan kelengkapan imunisasi dasar di wilayah kerja Puskesmas Sekincau Kabupaten Lampung Barat. Nilai OR: 3,764 yang berarti ibu dengan sikap yang mendukung memiliki peluang 3,764 untuk memiliki bayi dengan 
imunisasi dasar yang lengkap dibandingkan dengan ibu dengan sikap yang tidak mendukung terhadap imunisasi dasar lengkap.

\section{PEMBAHASAN}

\section{Sikap Ibu}

Distribusi frekuensi sikap ibu tentang kelengkapan imunisasi dasar terbanyak dengan sikap yang kurang mendukung sebesar 50,55\% (46 orang). Berdasarkan hasil tersebut menunjukkan bahwa sikap ibu tentang imunisasi dasar masih kurang baik dimana hasil tersebut dapat berkaitan dengan tingkat pendidikan responden yang juga sebagian besar dengan pendidikan tamatan SMP (50,55\%) dimana pada ibu dengan tingkat pendidikan SMP tersebut terdapat 22 ibu dengan sikap yang tidak mendukung.

Sikap merupakan kesiapan untuk bereaksi terhadap suatu objek dengan cara tertentu, sikap merupakan respon evaluasi terhadap pengalaman kognisi, reaksi, afeksi, kehendak dan perilaku masa lalu dan manusia tidak dilahirkan dengan sikap pandangan ataupun perasaan tertentu, tetapi sikap dibentuk sepanjang perkembangannya.(Azwar 2011 )

Sikap merupakan reaksi atau respon yang masih tertutup dari seseorang terhadap suatu stimulus atau objek, manifestasi sikap itu tidak dapat langsung dilihat, tetapi hanya dapat ditafsirkan terlebih dahulu dari perilaku tertutup (Notoatmodjo, 2011). Newcomb dalam Notoatmodjo (2011) menyatakan bahwa sikap merupakan kesiapan atau kesediaan untuk bertindak, dan bukan merupakan pelaksanaan motif tertentu. Sikap belum merupakan suatu tindakan atau aktifitas, akan tetapi adalah merupakan "pre disposisi" tindakan atau perilaku. Sikap masih merupakan reaksi tertutup, bukan merupakan reaksi terbuka.

Hasil penelitian ini memiliki hasil yang lebih tinggi jika dibandingkan dengan penelitian yang telah dilakukan oleh Riyanto (2013) di Kampung Cantilan Kelurahan Kagungan Kecamatan Kasemen
Kota Serang dengan hasil distribusi frekuensi sikap responden tentang perilaku pelaksanaan imunisasi dasar pada balita diperoleh sebesar $30,3 \%$ memiliki sikap negatif.

Berdasarkan hasil tersebut maka sikap yang kurang mendukung dari ibu tersebut dapat dimungkinkan berkaitan dengan pengetahuan ibu tentang manfaat dari kelengkapan imunisasi dasar yang kurang baik sehingga mereka kurang menganggap penting dari pemberian imunisasi dasar tersebut serta hal ini juga berkaitan dengan tingkat pendidikan ibu yang sebagian besar adalah tamatan SLTP sehingga pengetahuan mereka juga masih kurang.

\section{Imunisasi Dasar}

Distribusi frekuensi kelengkapan imunisasi dasar pada balita terbanyak dengan imunisasi dasar yang tidak lengkap sebesar $63,74 \%$ (58 orang). Berdasarkan hasil tersebut menunjukkan bahwa masih banyak bayi yang belum mendapatkan imunisasi dasar, dimana kondisi ini tidak sesuai dengan kondisi yang diharapkan dimana setiap balita harus mendapatkan imunisasi dasar lengkap.

Imunisasi dasar merupakan salah satu cara pencegahan penyakit menular khususnya Penyakit yang Dapat Dicegah dengan Imunisasi (PS3I) yang diberikan tidak hanya kepada anak sejak bayi hingga remaja juga pada dewasa (Kemenkes RI, 2016). Cara kerja imunisasi yaitu dengan memberikan antigen bakteri atau virus tertentu yang sudah dilemahkan atau dimatikan dengan tujuan merangsang sistem imun tubuh untuk membentuk antibodi. Antibodi yang terbentuk setelah imunisasi berguna untuk menimbulkan kekebalan seseorang secara aktif sehingga dapat mencegah atau mengurangi akibat penularan PD3I tersebut (Kemenkes, 2016).

Hasil penelitian ini memiliki kesesuaian dengan hasil penelitian terdahulu oleh Riyanto (2013) di Kampung Cantilan Kelurahan Kagungan Kecamatan Kasemen Kota Serang dengan hasil distribusi frekuensi pelaksanaan imunisasi 
dasar pada balita diperoleh sebesar 65,8\% dengan perilaku imunisais yang tidak lengkap.

Berdasarkan hasil tersebut maka masih rendahnya cakupan imunisasi dasar pada responden penelitian $(36,26 \%)$ tersebut dapat dimungkinkan dengan kurang menyebarkan informasi kepada para seluruh ibu yang memiliki balita serta adanya halangan yang menyebabkan ibu tidak datang ke posyandu untuk memberikan imunisasi kepada bayinya terkait dengan pekerjaan mereka yang membantu suami untuk bekerja sebagai petani dan berkebun.

\section{Hubungan Sikap Ibu dengan Kelengkapan Imunisasi Dasar}

Hasil analisis hubungan sikap ibu dengan kelengkapan imunisasi dasar dari 46 ibu dengan sikap yang tidak mendukung terdapat 36 bayi $(78,3 \%)$ dengan imunisasi yang tidak lengkap, sedangkan dari 46 ibu dengan sikap yang mendukung terdapat 22 bayi $(48,9 \%)$ dengan imunisasi tidak lengkap. Hasil uji statistik chi square diperoleh bahwa nilai $\mathrm{p}$ value: 0,007 , yang berarti ada hubungan sikap ibu tentang imunisasi dasar dengan kelengkapan imunisasi dasar di wilayah kerja Puskesmas Sekincau Kabupaten Lampung Barat tahun 2018. Nilai OR: 3,764 yang berarti ibu dengan sikap yang tidak mendukung memiliki risiko 3,764 untuk memiliki bayi dengan imunisasi dasar yang tidak lengkap dibandingkan dengan ibu dengan sikap yang mendukung terhadap imunisasi dasar lengkap.

Adanya hubungan antara sikap ibu dengan kelengkapan imunisasi dasar lengkap tersebut tergambar dari persentase bayi yang imunisasi dasar yang tidak lengkap lebih besar dibandingkan dengan persentase pada ibu dengan sikap yang mendukung.

Hasil tersebut memiliki kesesuaian dengan teori yang menyebutkan bahwa perilaku seseorang dipengaruhi oleh sikapnya terhadap hal tersebut. Sikap merupakan juga kesiapan atau kesediaan untuk bertindak, dan bukan merupakan pelaksanaan motif tertentu. Sikap menggambarkan suka atau tidak suka seseorang terhadap obyek, yang diperoleh dari pengalaman atau dari orang terdekat (Notoatmodjo, 2007). Sikap akan diikuti oleh perilaku seseorang berdasarkan suka atau tidak suka terhadap hal tersebut. Jika ia mendukung hal tersebut maka ia akan berperilaku untuk melaksanakan hal yang ia dukung tersebut. Berdasarkan hal tersebut maka kelengkapan imunisasi dasar yang dilakukan ibu berkaitan dengan penerimaan atas manfaat yang mereka peroleh dari imunisasi dasar lengkap terhadap bayi mereka sehingga mereka dengan senang hati untuk melakukan imunisasi dasar lengkap terhadap bayinya.

Hasil ini memiliki kesamaan hasil dengan penelitian yang dilakukan oleh Umaroh (2014) di wilayah Kerja Puskesmas Kertasura Kabupaten Sukoharjo dengan hasil menunjukan hubungan yang bermakna antara sikap ibu dengan kelengkapan imunisasi dengan nilai $p$ value: 0,001 .

Berdasarkan teori dan hasil yang diperoleh dalam penelitian ini maka dapat diketahui bahwa sikap berhubungan dengan kelengkapan imunisasi dasar pada bayi. Ibu dengan sikap yang kurang mendukung akan cenderung tidak memperhatikan jadwal dari pemberian imunisasi dasar lengkap pada bayinya dibandingkan dengan ibu dengan sikap yang mendukung. Dengan sikap yang mendukung maka seseorang akan lebih baik dalam memberikan persepsi sesuatu yang ia ketahui.

Dalam penelitian ini juga terdapat ibu dengan sikap yang mendukung namun bayinya tidak mendapatkan imunisasi dasar lengkap $(48,9 \%)$ dimana hal tersebut dapat berkaitan dengan kesibukan ibu yang sebagian besar dengan pekerjaan petani seperti yang tergambar dalam demografi penduduk di wilayah kerja Puskesmas Sekincau yang sebagian besar adalah petani sehingga mereka terlewat untuk membawa bayinya mendapatkan imunisasi dasar lengkap, sedangkan pada ibu dengan sikap yang kurang mendukung namun bayinya tetap mendapatkan imunisasi dasar lengkap $(21,7 \%)$ dapat dimungkinkan 
karena perilaku ibu tersebut tidak didasari oleh apa yang ia pahami namun lebih cenderung karena faktor ikut-ikutan dengan ibu lain yang membawa bayinya ke posyandu untuk mengimunisasikan bayinya.

\section{KESIMPULAN}

Hasil penelitian menyimpulkan ada hubungan sikap ibu tentang imunisasi dasar lengkap dengan kelengkapan imunisasi dasar lengkap di wilayah kerja Puskesmas Sekincau Kabupaten Lampung Barat dengan p value: 0,007 OR: 3,764.

Selanjutnya penelitian menyarankan agar pihak puskesmas dapat memberikan motivasi kepada para kader posyandu untuk mengajak para ibu yang memiliki balita untuk memberikan imunisasi serta untuk lebih tertib admistrasi dalam melakukan pendataan terhadap jumlah balita yang sudah maupun beum mendapatkan imunisasi sehingga dapat diupayakan

\section{DAFTAR PUSTAKA}

Azwar, S. (2011), Sikap Manusia: Teori dan Pengukurannya (edisi 2), Pustaka Pelajar, Jakarta.

Kemenkes. (2016). Profil Kesehatan Indonesia Tahun 2015. Kemenkes. Jakarta

Kemenkes. (2017). Infodatin: Situasi Imunisasi di Indonesia. Kemenkes. Jakarta.

Kemenkes. (2016). Buku Ajar Imunisasi. Kemenkes. Jakarta.

Lisnawati, (2011), Generasi Sehat Melalui Imunisasi, Trans Info Media, Jakarta.

Notoatmodjo, S. (2014). Ilmu Perilaku Kesehatan, Rineka Cipta, Jakarta.

Puskesmas Sekincau, Laporan PTP Puskesmas Sekincai Tahun 2017, Sekincau Lampung Barat

Riyanto. (2013). Hubungan Pengetahuan dan Sikap Ibu Tentang Imunisasi Dasar dengan Perilaku Pelaksanaan Imunisasi Dasar pada Balita di Kampung Cantilan Kelurahan Kagungan Kecamatan Kasemen Kota Serang, diakses dari: http://ejournal.stikesborromeus.ac.id/ file/6-1.pdf 